\title{
The Relationship of Using Google Classroom for Effective Learning and Paperless to Student Learning Outcomes
}

\author{
Ismanisa $^{1 *}$, Manihar Situmorang ${ }^{2}$, Nurhaswinda $^{3}$ \\ ${ }^{1)}$ Department Magister Chemistry Education, State University of Medan, Indonesia \\ ${ }^{2}$ ) Department Chemistry, State University of Medan, Indonesia \\ ${ }^{3)}$ Department of Teacher Education Elementary School, Pahlawan Tuanku Tambusai \\ University, Riau, Indonesia \\ *ismaniisaiis@gmail.com
}

\begin{abstract}
This research aim to know the relationship between the using of Google Classroom as effective learning and paperless towards student learning outcomes. The quantitative research is used as a research method. The subjects of this study are the first semester students who are programming the General Chemistry of department Mathematics Education, Medan State University, and it was 32 people. The techniques of the data collection consist for questionnaires to use of Google Classroom and instrument test to use of cognitive learning outcomes. Based on the results, it was accessed that use of Google Classroom as effective and paperless learning has a correlation with learning outcomes, where $t_{\text {count }}$ is greater than $t_{\text {table }},(0.525>0.361)$ with sig. 0.002 , which shows that the $\mathrm{Ha}$ is accepted, where the correlation is moderate. It meant that there was an effect of used Google Classroom toward student learning outcomes, and the coefficient effect was $27.6 \%$.
\end{abstract}

Keywords: google classroom; effective learning; paperless; learning outcomes

\section{Introduction}

The world of education today is very much influenced by developments in information technology and the internet, so that learning methods are directed to be able to better utilize these technologies [1]. One of the alternative internet-based learning method that can be used is e-learning. E-learning is a learning model that is supported by the use of technology and internet. [2]. According to Alonso et al. [3] argue that e-learning is a new multimedia technology and internet. E-learning is used to increase the quality in the learning, and with elearning we can access to resources and services, as well as collaboration and distance exchange, or it can also be called Web-Based Instruction. So, it can be concluded that elearning is learning process that is developed based on internet-based technology and digital media, in practice this online learning can be done anywhere and anytime with interactive, effective, independent, easily accessible, and also characteristics is one form of the concept of distance learning. In this time, e-learning becomes a necessity for universities to assist in learning and teaching activities [4].

Google Classroom is one of the e-learning that is starting to develop at this time and has been used in education. In 2014, Google Apps for Education began introducing Google Classroom in the world of education. Google Classroom can be a tool to help teachers create 
and organize assignments quickly, communicate easily with students and teacher can classify each assignment to students paperless, so they can provide feedback efficiently [5]. The use of Google Classroom will make learning more effective and also students will be able to learning, listening, reading, and sending assignments from distance learning [1]. Google Classroom is a service that is feasible to be applied to education in Indonesia, because Google Classroom has the same structure as the current learning [6].

The current learning method is still teacher-centered, where the teacher uses visual device in the form of power point, whiteboards, and other visualization but does not yet utilize existing technologies such as Google Classroom. This happens because the teacher has not utilized the available technological facilities. The lack of use of instructional media makes students unenthusiastic in the learning process. Thus, this makes it difficult for students to understand general chemistry subjects which then have an impact on the low student learning outcomes. So, the Google Classroom can help learning goals to be easily implemented and can make it easier for teachers to learn to manage and deliver learning information precisely and accurately to students [4].

Google has provided Google Classroom which is designed to increase the internet-based learning experience. The features offered by Google Classroom are providing classrooms with paperless, can combined to other Google products such as Gmail, Google drive, Google form, YouTube and there is distance learning interaction between the teacher and students during the learning process, easier to manage learning process, more efficient, and the teacher can see the progress of student during the learning process with better [7]. Iftakhar [8] said the use of Google Classroom emphasizes toward the perception of teachers and students. The use of this platform can creates better interaction between teachers and students, while students with this platform are very helpful because they can easily get learning subject uploaded by their teachers.

The use of Google Classroom in the learning process is the first step taken to provide an overview and preparation for students in using information technology. This application service is assumed to be one alternative in answering the problems and challenges of learning in the classroom at this time. Such as the limited time available in the classroom, the lack of time to discuss in studying the subject matter, and the limited time to correct student assignments. In addition, Google Classroom can be a means of sharing lessons, sending assignments, and even assessing assignments collected by students, which are done through distance learning. This Google Classroom is used during learning process to measure the quality of learning and student learning outcomes. Learning by using the Google Classroom application as a learning medium will improve the quality of learning for the better and help students understand general chemistry lessons so that students will achieve better learning outcomes [9].

Another study conducted by Rachmadyanti \& Wicaksono about Google Classroom with the results obtained from this study is the use of Google classes can provide access to students in online learning. The teacher can provide learning even if not in class. This is a form of teacher supervision of students when outside class hours [10]. Furthermore, research on Google Classroom was also carried out by Nurfayanti and Nurbaeti, based on research results show that the use of e-learning specifically the use of Google Classroom was able to increase student motivation in the application of learning technology [11]. In this research about Google Classroom, researchers want to know the relationship between the using of Google Classroom as effective learning and paperless on student learning outcomes. 


\section{Research Method}

This research was used a Quasi Experiment Design. There are two variables used, namely the use of Google Classroom as an independent variable and cognitive learning outcomes as a dependent variable. The sample of this study is the first semester students who are programming the General Chemistry Mathematics Education Study Program, FMIPA Medan State University, amounting to 32 people. The researcher conducted a sampling using purposive sampling technique. In this study, students are taught to download Google Classroom program then the teacher places teaching materials (power points, videos, instructions, and assignments) in Google Classroom, and students download learning, ask questions, and submit assignments in Google Classroom.

This study uses two types of instruments, namely (1 Questionnaire with Likert scale category is used as an instrument to measure students' responses to the use of Google Classroom as effective learning and paperless, and (2) the instrument used to measure cognitive learning outcomes is a test. The technique of analyzing the test data is done by using the one sample t-test.

\section{Results and Discussion}

\subsection{Results}

\section{Analysis of Use of Google Classroom}

The variable in using Google Classroom consists of three dimensions, namely the knowledge, the benefits, and the advantages of Google Classroom. From these three dimensions 10 questions were made and declared valid. Determination of the score on a Likert scale consisting of four scores is 4 for the highest score and 1 for the lowest score.

The results of the questionnaire analysis with a total of 32 respondents that have been done, it was found that the use of Google Classroom obtained data with a maximum score of 40 and a minimum score of 22 . The frequency distribution can be seen in Table 1.

Table 1. Distribution of Frequency of Use of Google Classroom

\begin{tabular}{cccc}
\hline No & Interval & Frequency & Percentage \\
\hline 1 & $21-23$ & 1 & $3,13 \%$ \\
2 & $24-26$ & 0 & $0.00 \%$ \\
3 & $27-29$ & 10 & $31,25 \%$ \\
4 & $30-32$ & 8 & $25,00 \%$ \\
5 & $33-35$ & 1 & $3.13 \%$ \\
6 & $36-38$ & 9 & $28.12 \%$ \\
7 & $39-41$ & 3 & $9.37 \%$ \\
\hline & & 32 & $100.00 \%$ \\
\hline
\end{tabular}

Table 1 shows that the largest frequency lies in the class interval 27-29 with a frequency of 10 respondents $(31,25 \%)$, while the smallest frequency lies in the class interval 24-26 with a frequency of 0 respondents $(0 \%)$. 
Table 2. Distribution of Trends in the Use of Google Classroom

\begin{tabular}{ccccc}
\hline No & Interval & Frequency & Percentage & Category \\
\hline $\mathbf{1}$ & $<27$ & 1 & $3,13 \%$ & Low \\
$\mathbf{2}$ & $27-35$ & 19 & $59,37 \%$ & Moderate \\
$\mathbf{3}$ & $>35$ & 12 & $37,50 \%$ & High \\
\hline & 32 & $100,00 \%$ & \\
\hline
\end{tabular}

Table 2 shows that the frequency of using Google Classroom category is as low as 1 respondent $(3.13 \%)$, the moderate category is 19 respondents $(59,37 \%)$, and in the high category there are 12 respondents $(37,5 \%)$. This means that the tendency to use Google Classroom is directly proportional to the score obtained. If the higher the score obtained, the higher the students to use of Google Classroom and if the score obtained is lower then it can be said the lower the interest of students to use of Google Classroom to support the learning process.

\section{Analysis of Student Learning Outcomes}

The results of the test analysis that have been done, it was found that test scores of student learning outcomes after the use of Google Classroom were applied quite varied. As for the analysis table of the student learning outcomes can be seen in the following Table 3.

Table 3. Statistical Analysis of Student Learning Outcomes

\begin{tabular}{clr}
\hline No & Statistic & Statistic Analysis \\
\hline 1 & Subject & 32.00 \\
2 & Ideal value & 100.00 \\
3 & Average & 80.63 \\
4 & Maximum score & 100.00 \\
5 & Minimum score & 20.00 \\
6 & Range & 80.00 \\
7 & Standard Deviation & 16.64 \\
8 & Variance & 277.01 \\
\hline
\end{tabular}

Table 3 shows that the average of student learning outcomes in general chemistry courses is 80.63 with a standard deviation of 16.644 . Scores achieved by students are scattered with the maximum score of 100 to the minimum score of 20 of the highest possible score of 100 and the lowest possible score of 0 , with a range of 80 . The number of students who have completed this general chemistry subjects is 28 people (or $87.5 \%$ complete) and there are 4 people who have not yet completed the completeness score of 70 . Meanwhile, the average of student learning outcomes is 80.63 or in the high category. 
Table 4. Test Results for One Sample t-Test

\begin{tabular}{|c|c|c|c|c|c|c|}
\hline \multicolumn{7}{|c|}{ One-Sample Test } \\
\hline & \multicolumn{6}{|c|}{ Test Value $=70$} \\
\hline & \multirow{2}{*}{$\mathrm{t}$} & \multirow{2}{*}{$\mathrm{df}$} & \multirow{2}{*}{$\begin{array}{l}\text { Sig. (2- } \\
\text { tailed) }\end{array}$} & \multirow{2}{*}{$\begin{array}{c}\text { Mean } \\
\text { Difference }\end{array}$} & \multicolumn{2}{|c|}{$\begin{array}{l}\text { 95\% Confidence Interval of the } \\
\text { Difference }\end{array}$} \\
\hline & & & & & Lower & Upper \\
\hline $\begin{array}{l}\text { Learning } \\
\text { outcomes }\end{array}$ & 3.611 & 31 & .001 & 10.625 & 4.62 & 16.63 \\
\hline
\end{tabular}

Table 4 shows that $t_{\text {count }}=3.611>t_{\text {table }}=0.361$ with sig $=0.001<\alpha=0.05$. It mean that there was an effect toward learning outcomes after being taught by applying the use of Googl Classroom during learning process.

\section{Analysis of Hypothesis Test}

Table 5. Test the Correlation of the use Google Classroom with Learning Outcomes

Correlations

\begin{tabular}{clrr}
\hline & & Google Classroom & Learning outcomes \\
\hline Google & Pearson Correlation & 1 & $.525^{* *}$ \\
Classroom & Sig. (2-tailed) & & .002 \\
& $\mathrm{~N}$ & 32 & 32 \\
Learning & Pearson Correlation & $.525^{* *}$ & 1 \\
outcomes & Sig. (2-tailed) & .002 & 32 \\
& $\mathrm{~N}$ & 32 & \\
\hline **. Correlation is significant at the 0.01 level (2-tailed). & &
\end{tabular}

Table 5 shows that $r_{\text {count }}>r_{\text {table }}$ is obtained, $0.525 \geq 0.361$ with sig. $0.002<\alpha=0.05$. It concluded that $r_{\text {count }}$ was higher than $r_{\text {table. }}$. Ho was rejected and Ha was accepted. It mean that there was a relationship of using Google Classroom for effective learning and paperless to student learning outcomes. If interpreted into the correlation table, it is found that the relationship between the use of Google Classroom as effective learning towards learning outcomes is classified as moderate correlation.

Table 6. Effect of Use Google Classroom toward Learning Outcomes

\begin{tabular}{ccccc}
\hline \multicolumn{4}{c}{ Model Summary } \\
\hline Model & $\mathrm{R}$ & R Square & Adjusted R Square & Std. Error of the Estimate \\
1 & $.525^{\mathrm{a}}$ & .276 & .252 & 14.395 \\
\hline
\end{tabular}

a. Predictors: (Constant), Google Classroom

The regression test results in Table 6 were $27.6 \%$, while the remaining $72.4 \%$ were influenced by other variables. It mean that effective learning was not only affected by the use of Google Classroom during learning process, but also affected by several other aspects of learning. 


\subsection{Discussions}

The aim of this research is to know the correlation between the use of the Google Classroom application as effective and paperless learning on student learning outcomes in the first semester students who are programming the General Chemistry of department Mathematics Education, Medan State University.

The results on Table 1 shows that the largest frequency lies in the class interval 27-29 with a frequency of 10 respondents $(31,25 \%)$, while the smallest frequency lies in the class interval 24-26 with a frequency of 0 respondents $(0 \%)$. Whereas based on the category of using Google Classroom, it was found that getting a low category was 1 respondent $(3.13 \%)$, the moderate category is 19 respondents $(59,37 \%)$, and in the high category there were 12 respondents $(37,5 \%)$. This means that the tendency to use Google Classroom is directly proportional to the score obtained. If the higher the score obtained, the higher the students to use of Google Classroom and if the score obtained is lower then it can be said the lower the interest of students to use of Google Classroom to support the learning process.

The results of the assessment of student learning outcomes tests obtained that the test scores of student learning outcomes after the Google Classroom learning media is applied are quite varied. Based on Table 3, the average of student learning outcomes in general chemistry courses is 80.63 with a standard deviation of 16.644 . Scores achieved by students are scattered with the maximum score of 100 to the minimum score of 20 of the highest possible score of 100 and the lowest possible score of 0 , with a range of 80 . The number of students who have completed this general chemistry subjects is 28 people (or $87.5 \%$ complete) and there are 4 people who have not yet completed the completeness score of 70 . Meanwhile, the average of student learning outcomes is 80.63 or in the high category. In the table 4 shows that $\mathrm{t}_{\text {count }}=$ $3.611>\mathrm{t}_{\text {table }}=0.361$ with sig $=0.001<\alpha=0.05$. It mean that there was an effect toward learning outcomes after being taught by applying the use of Googl Classroom during learning process.

The relationship of use the Google Classroom as effective learning and paperless on learning outcomes is obtained $r_{\text {count }}>r_{\text {table }}$ is obtained, $0.525 \geq 0.361$ with sig. $0.002<\alpha=0.05$. It concluded that $r_{\text {count }}$ was higher than $r_{\text {table. }}$. Ha was accepted, it mean that there was a relationship of using Google Classroom for effective learning and paperless to student learning outcomes. If interpreted into the correlation table, it is found that the relationship between the using of Google Classroom as effective learning and paperless towards learning outcomes is classified as moderate correlation. The regression test was conducted to see the effect of Google Classroom in contributing to cognitive learning outcomes. The regression test results are $27.6 \%$, while the remaining $72.4 \%$ were affected by other variables. It mean that effective learning was not only affected by the use of Google Classroom during learning process, but also affected by several other aspects of learning.

The results of this research shows that the better use of Google Classroom will make students easly to access the lessons and learn the material provided by the teacher anywhere and anytime, so that it can increases student learning outcomes to be more optimal. Learning media as a learning tool that serves to smooth the course of learning process for the better. The use of Google Classroom effectively and efficiently in accordance with learning objectives will make the learning process more interesting, the learning process of students becomes more efficient, save more time in the learning process, can be improved the quality of learning, and the learning process can occur anywhere and anytime, but there must be access to the internet. so that it can make it easier for students to learn and can improve student learning outcomes. 
This research are in accordance with research from Panca \& Harimurti entitled "The Effect of Using Google Classroom Tools on Project Based Learning Models on Student Learning Outcomes". This shows that learning outcomes using project-based learning combined with Google Classroom are more effective in improving student learning outcomes [6]. Also in accordance with research Shofiah entitled "The Effect of Android Use and Elearning on Learning Outcomes". This research shows that there is a better influence on student learning outcomes by using Android as a learning resource and learning media, so that it can improve student learning outcomes [12]. So, the use of Google Classroom and paperless has a pretty good influence on student learning outcomes. The better students use Google Classroom during the learning process, students can improve their learning outcomes for the better.

\section{Conclusion}

The research can be concluded that the use of Google Classroom as effective learning and paperless has a correlation with students learning outcomes. The results of the product

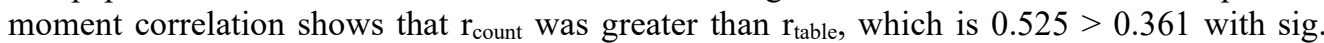
$0.002<\alpha=0.05$. Ha was accepted, it mean that there was a relationship of using Google Classroom for effective learning and paperless to student learning outcomes, where the correlation is moderate. The use of Google Classroom has a better contribution to cognitive learning outcomes in the amount of $27.6 \%$, while the remaining $72.4 \%$ were affected by other variables. It mean that effective learning was not only affected by the use of Google Classroom during learning process, but also affected by several other aspects of learning. This shows that the better students use Google Classroom during the learning process, students can improve their learning outcomes for the better.

\section{Reference}

[1] Soni, S., Hafid, A., Hayami, R., Fatma, Y., Wenando, F. A., Al Amien, J., ... \& Hasanuddin, H. (2018). Optimalisasi Penggunaan Google Classroom, E-Learning \& Blended Learning sebagai Media Pembelajaran bagi Guru dan Siswa Di SMK Negeri 1 Bangkinang. Jurnal Pengabdian Untuk Mu NegeRI, 2(1), pp.17-20.

[2] Hanum, N. S. (2013). Keefetifan E-Learning sebagai Media Pembelajaran (Studi Evaluasi Model Pembelajaran E-Learning SMK Telkom Sandhy Putra Purwokerto). Jurnal Pendidikan Vokasi, 3(1), pp.90-102.

[3] Alonso, F., López, G., Manrique, D., \& Viñes, J. M. (2005). An Instructional Model for Web Based E-Learning Education with a Blended Learning Process Approach. British Journal of Educational Technology, 36(2), pp.217-235.

[4] Hakim, A. B. (2016). Efektifitas Penggunaan E-Learning Moodle, Google Classroom dan Edmodo. I-STATEMENT, 2(1).

[5] Shaharanee, I. N. M., Jamil, J. M., \& Rodzi, S. S. M. (2016). The Application of Google Classroom as a Tool for Teaching and Learning. Journal of Telecommunication, Electronic and Computer Engineering (JTEC), 8(10), pp.5-8.

[6] Bagas Panca Pradana, D. (2017). Pengaruh Penerapan Tools Google Classroom pada Model Pembelajaran Project Based Learning terhadap Hasil Belajar Siswa. IT-EDU, $2(01)$. 
[7] Nurhayati, D., Az-Zahra, H. M., Herlambang, A. D., (2019). Evaluasi User Experience pada Edmodo dan Google Classroom Menggunakan Technique for User Experience Evaluation in E-Learning (TUXEL). Jurnal Pengembangan Teknologi Informasi dan Ilmu Komputer, e-ISSN: 2548-964X, 3(4), pp.3771-3780.

[8] Iftakhar, S. (2016). Google Classroom: What Works and How?. Journal of Education and Social Sciences, 3(1), pp.12-18.

[9] Windarti, A., \& Ardiansyah, A. N. (2018). Pengaruh Penggunaan Aplikasi Google Classroom Tehadap Kualitas Pembelajaran dan Hasil Belajar Siswa Pada Mata Pelajaran Ekonomi Kelas XI Di MAN 1 Kota Tangerang Selatan (Bachelor's thesis, Jakarta: Fakultas Ilmu Tarbiyah dan Keguruan UIN Syarif Hidayatullah).

[10] Rachmadyanti, P., \& Wicaksono, V. D. (2016, August). Pendidikan Kewirausahaan bagi Anak Usia Sekolah Dasar. In Prosiding Seminar Nasional Inovasi Pendidikan.

[11] Nuvrfayanti, N., \& Nurbaeti, N. (2019). Pengaruh Media Pembelajaran Google Classroom dalam Pembelajaran Analisis Real Terhadap Motivasi Belajar Mahasiswa. Proximal: Jurnal Penelitian Matematika dan Pendidikan Matematika, 2(1).

[12] Shofiyah, S. (2016). Pengaruh Penggunaan Android dan E-Learning terhadap Hasil Belajar Mata Pelajaran IPS Siswa Kelas VIII SMPN 3 Kepanjen Malang (Doctoral dissertation, Universitas Islam Negeri Maulana Malik Ibrahim). 